\title{
Consensus-based care recommendations for adults with myotonic dystrophy type 2
}

Benedikt Schoser, MD, Federica Montagnese, MD, Guillaume Bassez, MD, PhD, Barbara Fossati, MD, Josep Gamez, MD, PhD, Chad Heatwole, MD, James Hilbert, MS, Cornelia Kornblum, MD, Anne Kostera-Pruszczyk, MD, PhD, Ralf Krahe, PhD, Anna Lusakowska, MD, PhD, Giovanni Meola, MD, Richard Moxley III, MD, Charles Thornton, MD, Bjarne Udd, MD, PhD, and Paul Formaker, on behalf of the Myotonic Dystrophy Foundation

Neurology: Clinical Practice August 2019 vol. 9 no. 4 343-353 doi:10.1212/CPJ.0000000000000645

\section{Correspondence}

Paul Formaker

Leah.Hellerstein@myotonic.org

\section{Abstract}

\section{Purpose of review}

Myotonic dystrophy type 2 (DM2) is a rare, progressive multisystem disease particularly affecting the skeletal muscle. A causal therapy is not yet available; however, prompt, appropriate symptomatic treatments are essential to limit disease-related complications. Evidence-based guidelines to assist medical practitioners in the care of DM2 patients do not exist.

\section{Recent findings}

The Myotonic Dystrophy Foundation (MDF) previously worked with an international group of 66 clinicians to develop consensusbased care recommendations for myotonic dystrophy type 1 . Following a similar approach, the MDF recruited 15 international clinicians with long-standing experience in the care of DM2 patients to develop consensus-based care recommendations. The single text procedure was adopted. This process generated a 4-page Quick Reference Guide and a comprehensive 55-page document that provides care recommendations for DM2 patients.

\section{Summary}

The resulting recommendations will help standardize and improve care for DM2 patients and facilitate appropriate management in centers without neuromuscular specialists.

Myotonic dystrophy type 2 (DM2), also known as proximal myotonic myopathy, is a rare, multi-systemic disease similar to but distinct from myotonic dystrophy type-1 (DM1). DM2 has a later onset, usually milder phenotype, and lacks the severe congenital form seen in DM1. The gene defect in DM2 is an unstable CCTG repeat expansion in the cellular nucleic acidbinding protein gene (cellular nucleic acid-binding protein-formerly known as ZNF9 gene). ${ }^{1}$ Like DM1, DM2 has an autosomal dominant inheritance pattern and expansion lengths of 75 repeats or longer are considered pathogenic. ${ }^{1}$ 
DM2 has a later onset, usually milder phenotype, and lacks the severe congenital form seen in DM1.

The CCTG-expansion is extremely unstable. It increases with age and shows marked heterogeneity in length within different tissues of the same subject. ${ }^{2}$ Unlike DM1, there is no clear correlation between the length of the CCTG expansion and clinical severity. Symptoms in DM2 patients usually begin in the third to fifth decades of life. No congenital or infantile cases have been reported. Muscular symptoms are usually the major complaints that cause patients to see a physician. However, extramuscular manifestations, such as cataracts, may precede the muscular complaints. Muscle weakness and/or myalgia are the most common symptoms at onset, whereas about $40 \%-50 \%$ of patients initially complain of myotonia/muscle stiffness. ${ }^{3,4}$ As the duration of DM2 increases many organs and systems may be affected; hence, the patient's management should include screening for heart diseases (cardiomyopathy, arrhythmias), diabetes mellitus/insulin resistance, thyroid dysfunctions, cataract, gastrointestinal disturbances, respiratory involvement, mild cognitive disorders, and tumors. ${ }^{5-8}$ Symptom severity widely varies among patients, even within members of the same family. Age-dependent worsening of muscular symptoms and an increase of the multi-systemic complications has been observed. ${ }^{4}$

Because of the low diagnosed prevalence of DM2 patients worldwide and the relatively recent discovery of this disease, there is a lack of rigorous evidence regarding the care and management of patients. For this reason, evidence-based guidelines cannot currently be developed. Consensus-based clinical care recommendations can serve as a support and guide for clinicians not familiar with the heterogeneous nature of DM2, enabling quality, standardized patient care for those living with DM2.

\section{Methodology}

The Myotonic Dystrophy Foundation (MDF) recruited clinicians from the United States and Europe who have experience in the treatment of patients with DM2 to develop consensus-based care recommendations.

The project included a total working group of 15 clinical professionals. MDF provided project design, development, and management support. A complete list of working group members and authors is provided below.

The principles of the single text procedure were mainly adopted to steer the consensus-building process. ${ }^{9}$ The single text procedure employs the use of a single document as a starting point to incorporate the input and contributions of stakeholders. In this approach, stakeholders add, subtract, and refine a draft text that becomes the foundation for a final ratified document.

This consensus-building model was selected because it could be effective within the context of the limited clinical care data available for DM2, the clinical content already available, and the complexities of working across a large, international group of experts.

Having already developed consensus-based care recommendations for $\mathrm{DM}^{10}$ and given the similarity of system involvement and management between DM1 and DM2, MDF created a draft document for DM2 based on DM1-consensus care recommendations (for further methodological details, refer to the Consensus-based Care Recommendations for Adults with Myotonic Dystrophy Type 1, 2018, myotonic.org/ clinical-resources).

MDF circulated the draft document to working group members who read the draft content and provided their recommendations. MDF aggregated all the revisions and suggestions into a single updated document. Recommendations in conflict were circulated within the group for discussion and resolved through serial conference calls.

These efforts led to the final consensus-based care recommendations and Quick Reference Guide for DM2, which were completed in mid-2018. The Quick Reference Guide content is provided as an appendix, and the full document is available online (appendix e-1, links.lww.com/CPJ/A88). Both feature flowcharts and other infographics for ease of use.

\section{Results}

See full recommendations at Neurology.org/cp.

\section{Life-threatening symptoms-Clinical care recommendations}

- Cardiovascular management

- DM2-related cardiac pathophysiology, although affecting all myocardial tissues, preferentially targets the cardiac conduction system. Conduction system defects are progressive and, although initially asymptomatic, increase the risk for symptomatic arrhythmias.

\section{Consensus-based clinical care} recommendations can serve as a support and guide for clinicians not familiar with the heterogeneous nature of DM2, enabling quality, standardized patient care for those living with DM2. 
- Significant cardiac involvement that subsequently leads to adverse cardiac events is often asymptomatic.

- At diagnosis, check for cardiac symptoms, perform a 12-lead ECG, and consider a 24-hour Holter ECG.

- Conduction abnormalities on a standard 12-lead ECG including sinus rate $<50$ beats per minute, PR interval $>200 \mathrm{~ms}$, QRS duration $>100 \mathrm{~ms}$, left anterior or posterior fascicular block, abnormal Q-waves, atrial tachycardia, fibrillation, or flutter, and ventricular arrhythmias are indicative of cardiac involvement.

- Refer patients with cardiac symptoms, abnormal annual 12-lead ECG indicative of cardiac involvement, and patients older than 40 years without previous cardiac evaluation to a cardiologist for further evaluation.

- See Flowchart figure 1 in Quick Reference Guide (appendix, links.lww.com/CPJ/A87).

- See full recommendations at myotonic.org/clinicalresources.

- Respiratory management

- Some DM2 patients have significant breathing problems that can result from muscle weakness of the diaphragm, abdominal and intercostal muscles, and myotonia of these muscles, leading to poor ventilatory force and resulting in low blood oxygen and elevated blood carbon dioxide levels.

- Clinicians must look for respiratory symptoms in DM2 patients.

- In asymptomatic patients, a pulmonary function assessment every 2 years is recommended.

- Refer DM2 patients with respiratory symptoms including ineffective cough (normal peak expiratory cough flow rate is $>270 \mathrm{~L} / \mathrm{min}$ ), respiratory insufficiency, recurrent pulmonary infections, prominent snoring, and maximal inspiratory pressure $<60 \mathrm{cmH}_{2} \mathrm{O}$ or forced vital capacity values of $50 \%$ less than predicted normal values to a pulmonologist knowledgeable in neuromuscular disorders.

- Vaccinate for pneumonia and flu; treat respiratory infections quickly and use cough assistance and mechanical ventilation as needed along with obtaining consultations from respiratory therapy and pulmonary medicine groups.

- Some patients will eventually require nighttime ventilator support. Most patients with chronic respiratory insufficiency respond to noninvasive ventilatory support (NIV).

- For chronic respiratory insufficiency, use supplemental oxygen with caution and in conjunction with NIV.

- If surgery is planned, reassess clearance capacity if needed, possible adaptation to NIV or cough assistance.

- See Flowchart figure 2 in Quick Reference Guide (appendix, links.lww.com/CPJ/A87).

- See full recommendations at myotonic.org/clinicalresources.

\section{Severe symptoms-Clinical \\ care recommendations}

\section{- Pain control}

- Muscle pain can occur in the neck, back, shoulders, hip flexors, and lower limbs. Statin-induced myopathy is often accompanied by muscle pain.

- Treat with conventional pain medications, which may be useful in treating the painful aspects of myotonic dystrophy (e.g., Ibuprofen).

- Opioids can be used but should be avoided if possible. If implemented, low doses should be used with close monitoring for side effects (see Anesthesia and surgery).

- Other remedies, such as massage, nerve blocks, heat/ ice, or chiropractic can be used. Some patients have reported that cannabis, cannabinoids, or phytocannabinoids ease pain; however, this needs to be proven in controlled clinical trials.

- Refer to Physical Therapy or Occupational Therapy if conventional treatment is not successful.

- See full recommendations at myotonic.org/clinicalresources.

- Skeletal muscle weakness and rehabilitation Skeletal muscle weakness and myalgia are major features of DM2.

- Initial weakness is in proximal hip girdle and neck (flexors > extensors) muscles. Axial muscle weakness is frequent in DM2 and may result in lower back pain.

- The progression is relatively slow, $1 \%-3 \%$ percent per year.

- Mild ptosis might be occasionally present. Calf hypertrophy may occur.

- Myalgia can be the most prominent clinical feature in the early stages and may severely affect occupational performance.

- Impacts to employment and activities of daily living occur because of the proximal and axial muscle weakness (e.g., climbing stairs and standing up from the floor)

- Treat with moderate- or low-intensity aerobic and resistance exercise, orthoses, or braces. It is advised to obtain a cardiac evaluation before starting a new exercise routine.

- See full recommendations at myotonic.org/clinicalresources.

- Skeletal muscle myotonia

- Myotonia-a sustained muscle contraction and difficulty in relaxing muscles-may occur and be symptomatic in DM2 patients.

- Myotonia can contribute to muscle stiffness, pain, prolonged hand grip, speech and swallowing difficulties, and gastrointestinal issues.

- Mexiletine may be considered in select patients for myotonia treatment of the hands with appropriate cardiac monitoring. 
- See full recommendations at myotonic.org/clinicalresources

- Ocular symptoms

- Major and clinically relevant eye manifestations in DM2 can include the following: cataracts, eyelid ptosis and incomplete eyelid closure, retinal changes and changes in intraocular pressure.

- Bilateral eyelid ptosis is a rare feature of DM2, but can occur in some patients.

- See full recommendations at myotonic.org/clinicalresources.

- Gastrointestinal symptoms

- Limited information is available, and manifestations are less severe than in DM1.

- Ask about problems with chewing, swallowing, drooling, reflux, bloating, abdominal pain, bowel movement frequency and characteristics, diarrhea, and incontinence.

- Physical examination should include abdominal palpation, including around gall bladder, and rectal examination for anal sphincter spasm and dyssynergic defecation for symptomatic patients.

- DM2 patients are at risk for pseudo-obstruction and experience other problems that may cause actual obstruction of small or large intestine, including endometriosis, acute gallbladder inflammation, ruptured ovarian cysts, and sigmoid volvulus. Monitor potential obstructions to determine whether they are pseudo or actual and treat accordingly.

- Nonmedical interventions:

- High-fiber diet for diarrhea or constipation; increase water intake

- Nutritional supplement for weight loss, weight gain, or dysphagia

- Dysphagia therapy referral for oral pharyngeal dysphagia

- Possible medical interventions:

- Loperamide for diarrhea control

- Laxatives for constipation:

- First-line therapy: Miralax, Senna, Ducosate, or Linaclotid

- Second-line therapy: Bisacodyl, Lubiprostone, or Linaclotide

- Metoclopramide for gastroparesis, pseudoobstruction, reflux

- Antibiotics for bacterial overgrowth-induced diarrhea (based on breath testing)

- Enteral feeding only for recurring pneumonia or severe dysphagia causing weight loss or causing inability to swallow safely without recurrent aspiration

- Mexiletine may be considered to treat diarrhea or constipation in DM2; however, its use for these indications requires further study.
- See full recommendations at myotonic.org/clinicalresources.

- Neuropsychiatric symptoms

- Advise patients that DM2 is also a "brain disorder" that can involve cognitive deficits and changes in cognition over time.

- Include psychiatric and behavioral examination at baseline and during regularly scheduled follow-up appointments or when symptoms appear.

- Refer patients with psychiatric or behavioral disorders and patients with cognitive complaints to a mental health care professional for testing and follow-up; patients may have limited insight into these issuesconsider input from partners and family members as appropriate.

- Treat with psychostimulants if apathy is associated with an impairing level of fatigue or excessive daytime sleepiness (EDS) (see Excessive daytime sleepiness) or antidepressant medication (cardiac examination before starting treatment, including a 12-lead ECG).

- See full recommendations at myotonic.org/clinicalresources.

- Excessive Daytime Sleepiness symptoms

- EDS is very rare in DM2 but can be a life-altering symptom. In contrast, fatigue is relatively common in DM2 and may be seriously disabling.

- Assess for EDS with Epworth Sleepiness Scale or similar standardized questionnaire instrument; prescribe sleep study if sleep disturbance is suspected.

- Monitor periodic limb movements (muscle activity during sleep), as well as EEG, and respiratory measures during sleep study to assess possible obstructive sleep apnea and CNS-mediated sleep apnea.

- Refer to pulmonologist and/or sleep specialist if EDS scores are positive on scales.

- Question patients regarding alcohol or caffeine consumption, medications, and sleep habits for contribution to EDS.

- Evaluate effect of possible respiratory muscle weakness (forced vital capacity value, sitting and supine) on presence of EDS.

- If nocturnal or daytime hypoventilation is suspected, consider noninvasive positive pressure ventilation, and refer to a pulmonologist with experience in neuromuscular diseases regarding possible need for NIV.

- Consider modafinil for treatment if coexisting CNS alteration is suspected as the cause for EDS.

- Consider cognitive behavioral therapy or behavioral therapy for apathy; also help treat fatigue; psychostimulant treatment can be considered if apathy is associated with an impairing level of fatigue or EDS.

- See full recommendations at myotonic.org/clinicalresources. 
- Endocrine and metabolic symptoms

- Follow criteria from American Diabetes Association regarding the type of initial testing to obtain, typically fasting blood glucose or $\mathrm{HbAlc}$ and if symptomatic diabetes is suspected.

- Consider formal glucose tolerance testing to monitor glucose control in patients; request serial measurement of $\mathrm{HbAlc}$ and fasting plasma glucose annually and coordinate care with diabetes specialist as necessary.

- Consider treating insulin resistance with lifestyle changes in diet and exercise.

- Measure liver and bilirubin levels at baseline and annually; chronic liver enzyme elevation is typical and does not necessarily indicate the need for obtaining a liver biopsy.

- Request thyroid-stimulating hormone (TSH) and circulating thyroid hormone (TSH and Free T4) level tests at baseline and at least every 3 years; more frequently if indicated.

- Test for hyperlipidemia using serum blood lipid levels at baseline and every 3 years; more frequently if indicated. Treat hyperlipidemia per current practice.

- Gender-specific recommendations:

- Women: Inquire about painful or irregular menses; ovarian cysts; endometriosis, reproductive history.

- Men: Inquire about erectile dysfunction; consider further workup and medications to treat erectile dysfunction. Consider possible cardiovascular risks-side effects associated with some erectile dysfunction medications (over the counter and prescribed).

- Inquire about infertility and family planning.

- See full recommendations at myotonic.org/clinicalresources.

- Tumors

- Follow general population cancer screening guidelines, particularly for breast, testicular, cervical, and colon cancer.

- Evaluate suspicious new CNS, abdominopelvic and thyroid symptoms for possible cancer; consider cancers of the brain, uterus, and ovary.

- See full recommendations at myotonic.org/clinicalresources.

- Pregnancy and obstetric management

- The effects of DM2 on both smooth and striated muscle can complicate pregnancy, labor and delivery, and increase myotonia.

- Prenatal and preimplantation genetic diagnosis can allow for termination of the pregnancy or selective implantation of unaffected embryos if desired.

- See full recommendations at myotonic.org/clinicalresources.
- Surgery, anesthesia, and pain

- Although a higher incidence of adverse reactions to medications used for anesthesia and analgesia has been reported for DM1 (about 8\%), it is yet not clear whether similar risks occur also in DM2 patients. However, given this uncertainty and the potentially serious complications reported in some DM2 patients, our advice is to adopt similar anesthesia guidelines as suggested for DM1.

- See MDF's Practical Suggestions for the Anesthetic Management of a Myotonic Dystrophy Patient (myotonic.org/clinical-resources) for anesthesia risks and recommendations before any surgeries or procedures requiring anesthesia.

- See full recommendations at myotonic.org/clinicalresources.

\section{Conclusions}

These consensus-based care recommendations for patients with DM2 are the product of an international group of experienced clinicians. They are intended to lead to more informed and prepared clinical professionals and more readily available and high-quality care for affected families.

\section{Acknowledgment}

This project would not have been possible without the major commitment made by the 15 international professionals involved in its development. MDF team leads included Paul Formaker, Leah Hellerstein, and Molly White.

\section{Study funding}

Myotonic Dystrophy Foundation.

\section{Disclosure}

B. Schoser serves on the scientific advisory boards of and received funding for travel from Sanofi-Genzyme, Biomarin, Amicus Therapeutics, and Audentes Therapeutics; serves on the editorial boards of Neuromuscular Disorders and Journal of Neuromuscular Disorders; and as a Section Editor for Current Opinion in Neurology. F. Montagnese served on a scientific advisory board organized by Lupin Europe $\mathrm{GmbH}$ for the approval of mexiletin for the treatment of myotonia. G. Bassez serves on the scientific advisory boards of Lupin pharmaceuticals, AFM-Telethon, and Myotonic Dystrophy Foundation; serves as a consultant for Lupin pharmaceuticals; and receives research support from FP7 EU, AFM-Telethon, and Myotonic dystrophy registry. B. Fossati and J. Gamez report no disclosures. C. Heatwole serves on the scientific advisory boards of Biogen; has received funding for travel from Myotonic Dystrophy Foundation; serves as a consultant for Imedecs, Maximus, Johns Hopkins University, Biogen, Atyr, Ionis, Acceleron, Cytokinetics, ExpansionRX, AMO, and the Marigold Foundation; receives research support from Pfizer, 
Technology Development Fund (University of Rochester), Cure Spinal Muscular Atrophy, Amyotrophic Lateral Sclerosis Association, Huntington Study Group/NJ Cure HD Foundation, NIH (NIAMS, NINDS), and United States Food and Drug Administration; has royalties for use of the Myotonic Dystrophy Health Index (MDHI), a disease-specific patientreported outcome measure for use in clinical trials and royalties from licensing instruments for FSHD, congenital DM1, CMT, SMA, and Huntington disease; and has participated in medicolegal cases. J. Hilbert receives research support from Biogen, NIH, Abrams Family Fund, FSH Society, and Friends of FSH Research. C. Kornblum has received funding for travel or speaker honoraria from Sanofi-Genzyme, Santhera, Novartis, Stealth BioTherapeutics, Deutsche Gesellschaft für Muskelkranke e.V., and Marigold Foundation, Canada; has served as a consultant for Stealth BioTherapeutics; and receives research support from Stealth Biotherapeutics, BMBF (German Federal Ministry of Education and Research), mitoNET, Marigold Foundation, Canada, Deutsche Gesellschaft für Muskelkranke e.V., grant number Me4/1, since 2014. A. Kostera-Pruszczyk serves on the scientific advisory boards of Biogen, PTC, Sarepta, and Shire; has received honoraria from Kedrion, Baxter/ Shire, CSL Behring, and Sanofi Aventis; and serves on the editorial board of Neurology, Neurosurgery and Psychiatry. R. Krahe serves as an academic editor for PLoS One. A. Lusakowska and G. Meola report no disclosures. R. Moxley III serves on the scientific advisory boards of NIH/NINDS and Myotonic Dystrophy Foundation and receives research support from Ionis, NIH (NCRR, NCI), FDA, Saunders Family Foundation, and Abrams Family Fund. C. Thornton serves on the scientific advisory boards of the Myotonic Dystrophy Foundation and Dyne and on the NIH data safety monitoring board; has received funding for travel from University of Florida, University of Michigan, American Association of Neurology, Muscular Dystrophy Association, Myotonic Dystrophy Foundation, World Muscle Society, Fulcrum Therapeutics, Dyne Therapeutics, Lion Therapeutics, and Nature Conferences; is an author on patents regarding Modulation of Dystrophia Myotonica-Protein Kinase (DMPK) Expression; Compositions and Methods Related to Protein Displacement Therapy for Myotonic Dystrophy; and Methods and Compositions for Treatment of Diseases Associated with Aberrant Microsatellite Expansion; serves as a consultant for Isis Pharmaceuticals and Biogen Inc.; receives research support from Isis Pharmaceuticals, Biogen Inc., and NIH; and has received license fee payments/royalties from Isis Pharmaceuticals for model of myotonic dystrophy. B. Udd serves as an associate executive Editor for Neuromuscular Disorders and receives research support from Finnish Academy, the Sigrid Juselius Foundation, and the Jane and Aatos Erkko Foundation. P. Formaker reports no disclosures. Full disclosure form information provided by the authors is available with the full text of this article at Neurology.org/cp.

\section{Publication history}

Received by Neurology: Clinical Practice December 10, 2018. Accepted in final form February 18, 2019.

\section{Appendix Authors}

\begin{tabular}{llll}
\hline Name & Location & Role & Contribution \\
\hline $\begin{array}{l}\text { Benedikt } \\
\text { Schoser, MD }\end{array}$ & $\begin{array}{l}\text { Ludwig- } \\
\text { Maximilians- } \\
\text { Universität, } \\
\text { Munich, Germany }\end{array}$ & Author & $\begin{array}{l}\text { Data acquisition, } \\
\text { drafting and revision } \\
\text { of the manuscript, } \\
\text { publication of draft } \\
\text { and revision }\end{array}$ \\
\hline $\begin{array}{l}\text { Federica } \\
\text { Montagnese, } \\
\text { MD }\end{array}$ & $\begin{array}{l}\text { Friedrich-Baur- } \\
\text { Institut, Munich, } \\
\text { Germany }\end{array}$ & Author & $\begin{array}{l}\text { Data acquisition, } \\
\text { drafting and revision } \\
\text { of the manuscript, } \\
\text { publication of draft } \\
\text { and revision }\end{array}$ \\
\hline
\end{tabular}

\begin{tabular}{|c|c|c|c|}
\hline $\begin{array}{l}\text { Guillaume } \\
\text { Bassez, MD, } \\
\text { PhD }\end{array}$ & $\begin{array}{l}\text { Institut de } \\
\text { Myologie, Paris, } \\
\text { France }\end{array}$ & Author & $\begin{array}{l}\text { Data acquisition, } \\
\text { drafting and } \\
\text { revision of the } \\
\text { manuscript }\end{array}$ \\
\hline
\end{tabular}

\begin{tabular}{lll}
\hline Barbara & U.O. Neurologia, Author & Data acquisition, \\
Fossati, MD & IRCCS Policlinico & drafting and \\
& San Donato, Milan, & revision of the \\
& Italy & manuscript \\
\hline
\end{tabular}

\begin{tabular}{|c|c|c|c|}
\hline $\begin{array}{l}\text { Josep Gamez, } \\
\text { MD, PhD }\end{array}$ & $\begin{array}{l}\text { Vall d'Hebron } \\
\text { University Hospital, } \\
\text { Barcelona, Spain }\end{array}$ & Author & $\begin{array}{l}\text { Data acquisition, } \\
\text { draft and revise } \\
\text { manuscript }\end{array}$ \\
\hline $\begin{array}{l}\text { Chad } \\
\text { Heatwole, } \\
\text { MD }\end{array}$ & $\begin{array}{l}\text { University of } \\
\text { Rochester, } \\
\text { Rochester, NY }\end{array}$ & Author & $\begin{array}{l}\text { Data acquisition, } \\
\text { drafting and } \\
\text { revision of the } \\
\text { manuscript }\end{array}$ \\
\hline
\end{tabular}

\begin{tabular}{|c|c|c|c|}
\hline $\begin{array}{l}\text { James } \\
\text { Hilbert, MS }\end{array}$ & $\begin{array}{l}\text { University of } \\
\text { Rochester, } \\
\text { Rochester, NY }\end{array}$ & Author & $\begin{array}{l}\text { Drafting and } \\
\text { revision of the } \\
\text { manuscript }\end{array}$ \\
\hline
\end{tabular}

\begin{tabular}{|c|c|c|c|}
\hline $\begin{array}{l}\text { Cornelia } \\
\text { Kornblum, } \\
\text { MD }\end{array}$ & $\begin{array}{l}\text { University Hospital } \\
\text { of Bonn, Bonn, } \\
\text { Germany }\end{array}$ & Author & $\begin{array}{l}\text { Data acquisition, } \\
\text { drafting and revision } \\
\text { of the manuscript }\end{array}$ \\
\hline $\begin{array}{l}\text { Anne } \\
\text { Kostera- } \\
\text { Pruszczyk, } \\
\text { MD }\end{array}$ & $\begin{array}{l}\text { Medical University } \\
\text { of Warsaw, } \\
\text { Warsaw, Poland }\end{array}$ & Author & $\begin{array}{l}\text { Data acquisition, } \\
\text { drafting and } \\
\text { revision of the } \\
\text { manuscript }\end{array}$ \\
\hline $\begin{array}{l}\text { Ralf Krahe, } \\
\text { PhD }\end{array}$ & $\begin{array}{l}\text { University of Texas } \\
\text { MD Anderson } \\
\text { cancer center }\end{array}$ & Author & $\begin{array}{l}\text { Data acquisition, } \\
\text { drafting and } \\
\text { revision of the } \\
\text { manuscript }\end{array}$ \\
\hline
\end{tabular}

\begin{tabular}{|c|c|c|c|}
\hline $\begin{array}{l}\text { Anna } \\
\text { Lusakowska, } \\
\text { MD, PhD }\end{array}$ & $\begin{array}{l}\text { Medical University } \\
\text { of Warsaw, } \\
\text { Warsaw, Poland }\end{array}$ & Author & $\begin{array}{l}\text { Data acquisition, } \\
\text { draft and revise } \\
\text { manuscript }\end{array}$ \\
\hline $\begin{array}{l}\text { Giovanni } \\
\text { Meola, MD }\end{array}$ & $\begin{array}{l}\text { Department of } \\
\text { Biomedical Sciences } \\
\text { for health University } \\
\text { of Milan, Milan, Italy }\end{array}$ & Author & $\begin{array}{l}\text { Data acquisition, } \\
\text { drafting and } \\
\text { revision of the } \\
\text { manuscript }\end{array}$ \\
\hline $\begin{array}{l}\text { Richard } \\
\text { Moxley III, } \\
\text { MD }\end{array}$ & $\begin{array}{l}\text { University of } \\
\text { Rochester, } \\
\text { Rochester, NY }\end{array}$ & Author & $\begin{array}{l}\text { Data acquisition, } \\
\text { drafting and } \\
\text { revision of the } \\
\text { manuscript }\end{array}$ \\
\hline $\begin{array}{l}\text { Charles } \\
\text { Thornton, } \\
\text { MD }\end{array}$ & $\begin{array}{l}\text { University of } \\
\text { Rochester, } \\
\text { Rochester, NY }\end{array}$ & Author & $\begin{array}{l}\text { Data acquisition, } \\
\text { draft and revise } \\
\text { manuscript }\end{array}$ \\
\hline $\begin{array}{l}\text { Bjarne Udd, } \\
\text { MD, PhD }\end{array}$ & $\begin{array}{l}\text { Tampere } \\
\text { University, } \\
\text { Tampere, Finland }\end{array}$ & Author & $\begin{array}{l}\text { Data acquisition, } \\
\text { draft and revise } \\
\text { manuscript }\end{array}$ \\
\hline $\begin{array}{l}\text { Paul } \\
\text { Formaker }\end{array}$ & $\begin{array}{l}\text { Myotonic } \\
\text { Dystrophy } \\
\text { Foundation, San } \\
\text { Francisco }\end{array}$ & $\begin{array}{l}\text { Corresponding } \\
\text { Author }\end{array}$ & $\begin{array}{l}\text { Obtaining funding, } \\
\text { drafting and review } \\
\text { of the manuscript, } \\
\text { study concept and } \\
\text { design }\end{array}$ \\
\hline
\end{tabular}




\section{Consensus-based Care Recommendations for Adults with Myotonic Dystrophy Type 2}

\section{Quick Reference Version}

Due primarily to a significant lack of rigorous data, no evidence-based guidelines exist to inform the clinical care of people living with myotonic dystrophy type 2 (DM2). In order to improve and standardize care for this disease now, 15 leading myotonic dystrophy (DM) clinicians in Europe, Canada and the United States have created the Consensus-based Care Recommendations for Adults with Myotonic Dystrophy Type 2. A complete list of authors is available below.

\section{Pain control}

- Muscle pain can occur in the neck, back, shoulders, hip flexors, \& upper legs. Statininduced myopathy is often accompanied by muscle pain

- Treat with conventional pain medications to address the painful aspects of DM2. (Ibuprofen, etc.)

- Opioids can be used but should be avoided if possible. If implemented, low doses should be used with close monitoring for side-effects (See Anesthesia \& surgery)

- Other remedies, such as massage, nerve blocks, heat/ice, or chiropractic may provide benefit in select patients. Anecdotally, some patients have reported that cannabis helps ease pain, however more research needs to be conducted (Jensen et al, 2008)
- Refer to physical therapy or occupational therapy if conventional treatment isn't successful

- See full recommendations at http://www.myotonic.org/clinical-resources

\section{Cardiovascular management}

DM2-related cardiac pathophysiology, although affecting all myocardial tissue, preferentially targets the cardiac conduction system. Conduction system defects are progressive \&, while initially asymptomatic, increase the risk for symptomatic arrhythmias.

- See full recommendations at http://www.myotonic.org/clinical-resources

Fig. 1 DM2 Cardiac Care Recommendations Flowchart

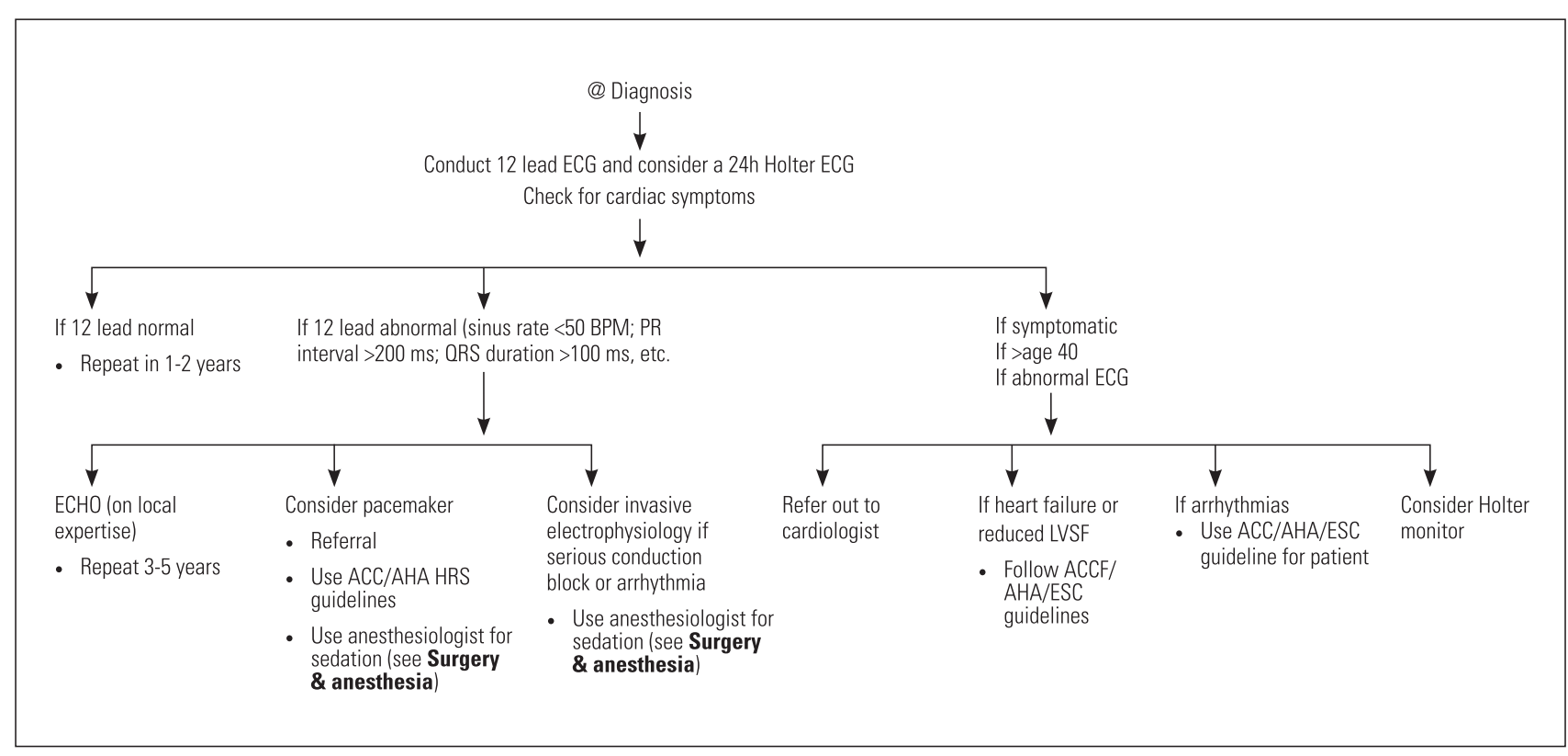




\section{Neuropsychiatric management}

- Advise patients that DM2 is also a 'brain disorder'

- Include psychiatric \& behavioral examination at baseline, \& during regularly-scheduled follow up appointments or when symptoms appear

- Refer patients with psychiatric or behavioral disorders, \& patients with cognitive complaints to mental health care professionals for testing \& follow up; patients may have limited insight into these issues - consider input from partners \& family members as appropriate

- Consider the use of psychostimulants if apathy is associated with an impairing level of fatigue or excessive daytime sleepiness (see excessive daytime sleepiness) or antidepressive medication (cardiac examination before starting treatment, including a 12 lead ECG)

- See full recommendations at http://www.myotonic.org/clinical-resources

\section{Respiratory management}

Some DM2 patients have significant breathing problems that can result from muscle weakness of the diaphragm, abdominal \& intercostal muscles \& myotonia of these muscles, leading to poor ventilatory force \& resulting in low blood oxygen \& elevated blood carbon dioxide levels.

- See full recommendations at http://www.myotonic.org/clinical-resources

\section{Excessive daytime sleepiness}

Excessive daytime sleepiness (EDS) \& fatigue may be life altering \& disabling in DM2.

- Assess for excessive daytime sleepiness (EDS) with Epworth Sleepiness Scale or similar standardized questionnaire instrument; prescribe sleep study if a sleep disturbance is suspected

- Monitor periodic limb movements (muscle activity during sleep), as well as EEG \& respiratory measures during sleep study to assess possible obstructive sleep apnea \& central nervous system mediated sleep apnea. Refer to pulmonologist \&/ or sleep specialist as needed if EDS scores are positive on scales

- Question patients re: alcohol or caffeine consumption, medications \& sleep habits for contribution to EDS

- Evaluate impact of possible respiratory muscle weakness (forced vital capacity value sitting \& supine) on the presence of EDS

- If nocturnal or daytime hypoventilation is suspected, consider non-invasive positive pressure ventilation, \& refer to a pulmonologist with experience in neuromuscular diseases re: possible need for NIV treatment

- Consider modafinil for treatment if coexisting central nervous system alteration is suspected as the cause for EDS

Fig. 2 DM2 Pulmonary Care Recommendations Flowchart

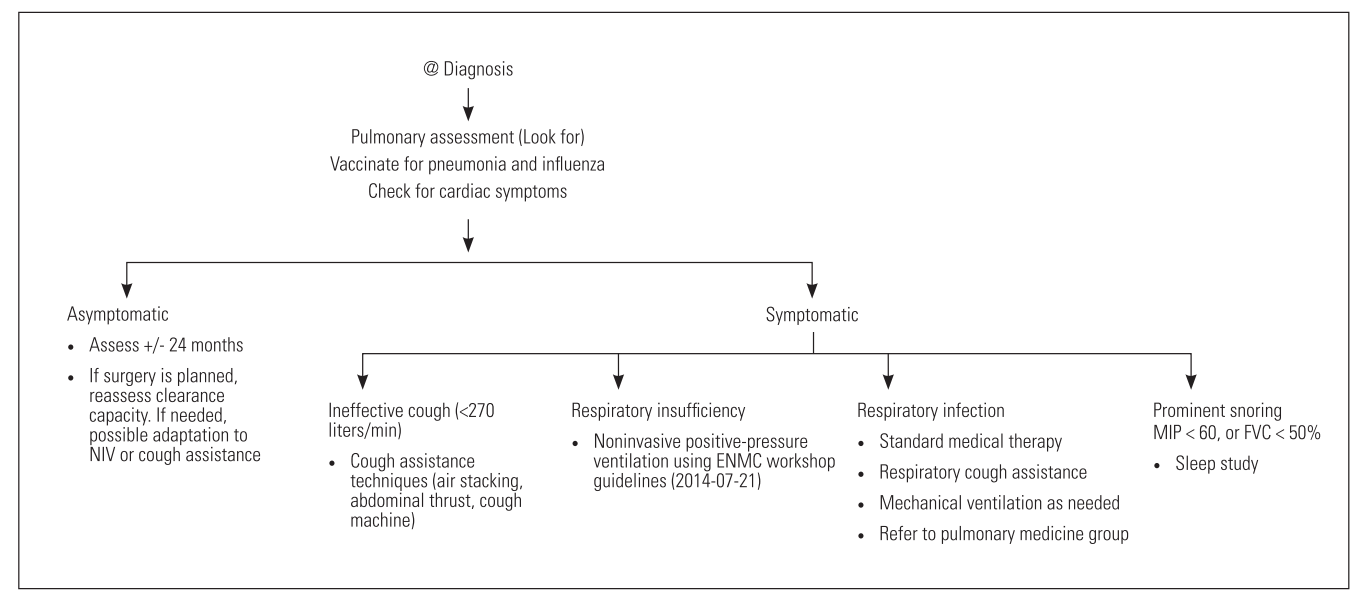


- Consider cognitive behavioral therapy (CBT) or behavioral therapy for apathy; psychostimulant treatment can be considered if apathy is associated with an impairing level of fatigue or EDS

- See full recommendations at http://www.myotonic.org/clinical-resources

\section{Skeletal muscle weakness \& rehabilitation}

Skeletal muscle weakness \& myalgia are major features of DM2 if bilateral \& progress at a relatively slow rate.

- Initial weakness is typically in the proximal hip girdle \& neck (flexors > extensors) muscles. Axial muscle weakness is frequent in DM2 \& may result in lower back pain

- Mild ptosis might be occasionally present. Calf hypertrophy may occur

- Myalgic pains can be the most prominent clinical feature in the early stages \& may severely affect occupational performance

- Neck flexor weakness can occur causing difficulty raising the head from a surface

- Treat with moderate- or low-intensity aerobic $\&$ resistance exercise, orthoses or braces. It is advisable to obtain a cardiac evaluation prior to starting a new exercise routine

- See full recommendations at http://www.myotonic.org/clinical-resources

Skeletal muscle myotonia

- Myotonia - sustained muscle contraction \& difficulty relaxing muscles may be present

- Myotonia can contribute to muscle stiffness, muscle locking, pain, prolonged hand grip, speech \& swallowing difficulties, \& Gl issues \& may be associated with hand tremor

- Mexiletine may be considered for myotonia treatment. Mexiletine is contraindicated for DM2 patients with cardiac involvement

- See full recommendations at http://www.myotonic.org/clinical-resources

\section{Gastrointestinal management}

Ask about problems with chewing, swallowing, drooling, reflux, bloating, abdominal pain, bowel movement frequency \& characteristics, diarrhea \& incontinence

- $\quad$ DM2 patients are at risk for pseudo-obstruction, \& may experience other problems that cause actual obstruction of small or large intestine, including endometriosis, acute gallbladder inflammation, ruptured ovarian cysts, sigmoid volvulus

- Monitor potential obstructions to determine whether they are pseudo or actual \& treat accordingly

- Non-medical interventions:

- High-fiber diet for diarrhea or constipation; increase water intake

- Nutritional supplement for weight loss, weight gain or dysphagia

- Dysphagia therapy referral for oral pharyngeal dysphagia

- Medical interventions:

- Loperamide (gentle use) for diarrhea control

- Laxatives for constipation:

- First line therapy: Miralax, Senna, Ducosate or Linaclotide

- Second line therapy: Bisacodyl, Lubiprostone, Linaclotide

- Metoclopramide for gastroparesis, pseudoobstruction, reflux

- Antibiotics for bacterial overgrowth-induced diarrhea (based on breath testing)

- See full recommendations at http://www.myotonic.org/clinical-resources 


\section{Ocular management}

Major \& clinically relevant eye manifestations in DM2 can include the following: cataracts, eyelid ptosis \& incomplete eyelid closure, retinal changes $\&$ changes in intraocular pressure.

- See full recommendations at http://www.myotonic.org/clinical-resources

\section{Pregnancy \& obstetrics management}

The effects of DM2 on both smooth \& striated muscle can complicate pregnancy, labor \& delivery.

Prenatal \& preimplantation genetic diagnosis can allow for termination of the pregnancy or selective implantation of unaffected embryos if desired.

- See full recommendations at http://www.myotonic.org/clinical-resources

\section{Surgery \& anesthesia}

Although a higher incidence of adverse reactions to medications used for anesthesia \& analgesia has been reported for DM1 (about $8 \%$ ), it is yet not clear whether similar risks occur also in DM2 patients. However, given this uncertainty $\&$ the potentially serious complications reported in some DM2 patients, our advice is to adopt similar anesthesia guidelines as suggested for DM1.

See the Myotonic Dystrophy Foundation's Practical Suggestions for the Anesthetic Management of a Myotonic Dystrophy Patient: http://www.myotonic. $\mathrm{org} / \mathrm{mdf}$-releases-updated-anesthesia-guidelines \& Anesthesia Quick Reference Guide at http://www. myotonic.org/clinical-resources

\section{Endocrine \& metabolic}

Fig. 3 Endocrine and Metabolic Care Recommendations Flowchart

\begin{tabular}{|c|c|c|c|c|c|}
\hline \multicolumn{6}{|c|}{ @ Diagnosis } \\
\hline & & & & $\underset{\downarrow}{\downarrow}$ & \\
\hline$\downarrow$ & $\downarrow$ & $\downarrow$ & $\downarrow$ & $\downarrow$ & $\downarrow$ \\
\hline $\begin{array}{l}\text { Request TSH and } \\
\text { free T4 at baseline \& } \\
\text { every } 3 \text { years, more } \\
\text { frequently if indicated }\end{array}$ & $\begin{array}{l}\text { Test for hyperlipidemia } \\
\text { via serum blood lipid } \\
\text { levels at baseline \& } \\
\text { every } 3 \text { years; more } \\
\text { frequently if indicated }\end{array}$ & $\begin{array}{l}\text { Follow ADA guidelines } \\
\text { for diabetes testing } \\
\text { - Consider formal } \\
\text { glucose tolerance } \\
\text { testing; Monitor HcA1c } \\
\text { \& FPG annually } \\
\text { - Treat insulin resistance } \\
\text { if detected }\end{array}$ & $\begin{array}{l}\text { Measure liver \& bilirubin } \\
\text { levels at baseline \& } \\
\text { annually. } \\
\text { - Chronic liver enzyme } \\
\text { elevation is typical \& } \\
\text { does not necessarily } \\
\text { indicate the need for } \\
\text { a liver biopsy }\end{array}$ & $\begin{array}{l}\text { Females: } \\
\text { - Inquire about irregular } \\
\text { menses; ovarian } \\
\text { cysts; indometriosis; } \\
\text { reproductive history }\end{array}$ & $\begin{array}{l}\text { Males: } \\
\text { - Inquire about ED, } \\
\text { consider further } \\
\text { workup/treatment }\end{array}$ \\
\hline
\end{tabular}

\section{Acknowledgments}

This project would not have been possible without the tireless and longterm commitment made by the 15 international professionals involved in its development. Each is experienced in the care and treatment of people living with myotonic dystrophy type 2. They included:

Guillaume Bassez, M.D., Ph.D. Institut de Myologie

Barbara Fossati, M.D.

U.O. Neurologia, IRCCS Policlinico San Donato

Josep Gamez, M.D., Ph.D.

Vall d'Hebron University Hospital

Chad Heatwole, M.D., MS-CI

University of Rochester

James Hilbert, M.S.

University of Rochester
Cornelia Kornblum, M.D.

University Hospital of Bonn

Anne Kostera-Pruszczyk, M.D. Medical University of Warsaw

Ralf Krahe, Ph.D.

University of Texas MD Anderson

Cancer Center

Anna Lusakowska, M.D., Ph.D.

Medical University of Warsaw

Giovanni Meola, M.D.

Department of Biomedical Sciences for Health

University of Milan
Federica Montagnese, M.D.

Friedrich-Baur-Institute, Ludwig-MaximiliansUniversity Munich

Richard Moxley III, M.D.

University of Rochester

Benedikt Schoser, M.D.

Friedrich-Baur-Institute, Ludwig-MaximiliansUniversity Munich

Charles Thornton, M.D. University of Rochester

Bjarne Udd, M.D., Ph.D.

Tampere University

An overview of the methodology used to develop consensus for these recommendations can be found here:

http://www.myotonic.org/clinical-resources 


\section{References}

1. Liquori CL, Ricker K, Moseley ML, et al. Myotonic dystrophy type 2 caused by a CCTG expansion in intron 1 of ZNF9. Science 2001;293:864-867.

2. Udd B, Meola G, Krahe R, et al. Report of the 115th ENMC workshop: DM2/ PROMM and other myotonic dystrophies. 3rd Workshop, 14-16 February 2003, Naarden, The Netherlands. Neuromuscul Disord 2003;13:589-596.

3. Day JW, Ricker K, Jacobsen JF, et al. Myotonic dystrophy type 2: molecular, diagnostic and clinical spectrum. Neurology 2003;60:657-664.

4. Montagnese F, Mondello S, Wenninger S, Kress W, Schoser B. Assessing the influence of age and gender on the phenotype of myotonic dystrophy type 2. J Neurol 2017; 264:2472-2480.

5. Meola G, Sansone V, Perani D, et al. Executive dysfunction and avoidant personality trait in myotonic dystrophy type 1 (DM-1) and in proximal myotonic myopathy (PROMM/DM-2). Neuromuscul Disord 2003;13:813-821.
6. Sansone VA, Brigonzi E, Schoser B, et al. The frequency and severity of cardiac involvement in myotonic dystrophy type 2 (DM2): long-term outcomes. Int J Cardiol 2013;168:1147-1153.

7. Sansone V, Gagnon C. Participants of the 207th ENMC Workshop. 207th ENMC Workshop on chronic respiratory insufficiency in myotonic dystrophies: management and implications for research, 27-29 June 2014, Naarden, The Netherlands. Neuromuscul Disord 2015;25:432-442.

8. Hilbert JE, Barohn RJ, Clemens PR, et al. High frequency of gastrointestinal manifestations in myotonic dystrophy type 1 and type 2. Neurology 2017;89:1348-1354. 9. Smith MS Single text negotiation. In: Beyond Intractability [Online]. Boulder: Conflict Information Consortium, University of Colorado. Available at: beyondintractability.org/essay/single-text- negotiation. Accessed October 21, 2018.

10. Ashizawa T, Gagnon C, Groh WJ, et al. Consensus-based care recommendations for adults with myotonic dystrophy type 1 . Neurol Clin Pract 2018;8:507-520. 


\section{Neurology ${ }^{\circ}$ Clinical Practice}

Consensus-based care recommendations for adults with myotonic dystrophy type 2

Benedikt Schoser, Federica Montagnese, Guillaume Bassez, et al.

Neurol Clin Pract 2019;9;343-353 Published Online before print April 24, 2019

DOI 10.1212/CPJ.0000000000000645

This information is current as of April 24, 2019

\begin{abstract}
Updated Information \& Services

References

Citations

Subspecialty Collections

Permissions \& Licensing

Reprints

including high resolution figures, can be found at: http://cp.neurology.org/content/9/4/343.full.html

This article cites 9 articles, 2 of which you can access for free at: http://cp.neurology.org/content/9/4/343.full.html\#\#ref-list-1

This article has been cited by 1 HighWire-hosted articles: http://cp.neurology.org/content/9/4/343.full.html\#\#otherarticles

This article, along with others on similar topics, appears in the following collection(s):

All Neuromuscular Disease

http://cp.neurology.org//cgi/collection/all_neuromuscular_disease Genetic linkage

http://cp.neurology.org//cgi/collection/genetic_linkage

Information about reproducing this article in parts (figures,tables) or in its entirety can be found online at:

http://cp.neurology.org/misc/about.xhtml\#permissions

Information about ordering reprints can be found online:

http://cp.neurology.org/misc/addir.xhtml\#reprintsus
\end{abstract}

Neurol Clin Pract is an official journal of the American Academy of Neurology. Published continuously since 2011, it is now a bimonthly with 6 issues per year. Copyright Copyright @ 2019 The Author(s). Published by Wolters Kluwer Health, Inc. on behalf of the American Academy of Neurology.. All rights reserved. Print ISSN: 2163-0402. Online ISSN: 2163-0933.

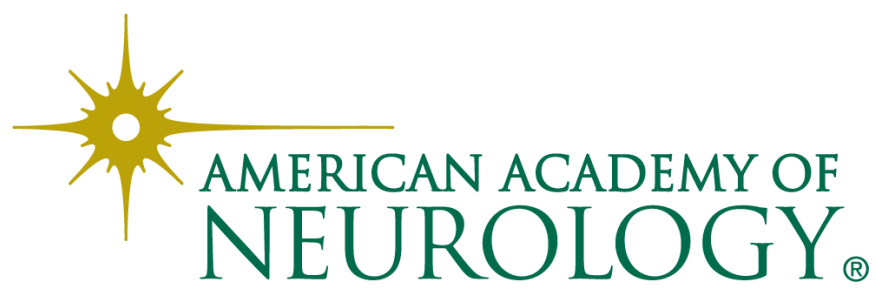

